\title{
Outside Europe
}

\section{The Hong Kong College of Medicine (1887-1915)}

\author{
JAMES KYLE
}

British Medical fournal, 1979, 1, 1474-1476

Visitors arriving for the joint clinical meeting of the British Medical Association in Hong Kong in November will land at Kai Tak International Airport. Kai perpetuates the memory of a talented local doctor who had a vital role in establishing the first British medical school in East Asia, and later in founding the University of Hong Kong.

In 1843, two years after Hong Kong island became a British possession, a medical missionary hospital was opened to provide the benefits of Western medical knowledge to the small Chinese population. Most of the Chinese, however, preferred traditional herbal remedies. The European-trained doctors were moved to other cities in mainland China, and the first hospital venture closed down after a few years. Further efforts by other missionary organisations failed for similar reasons. A purely Chinese hospital, the Tung Wah, was established in 1875 .

\section{Ho-family hospitals}

It was not until 1881 that a successful Western-style dispensary was opened. Dr William Young was born in Scotland, but graduated in medicine at McGill University, Montreal. With the help of the London Missionary Society and a small committee chaired by a local businessman, $\mathrm{Mr} \mathrm{H}$ W Davis, he opened a clinic at Tai Ping Shan, a crowded Chinese township on the northern or harbour side of the island. The dispensary flourished. Although the population was small by today's standards and the New Territories had not yet been leased, it was not long before thoughts were turning to building a proper hospital. A few months later the idea of creating a Hong Kong medical college for Chinese students was being discussed with enthusiasm.

Three graduates in medicine from the University of Aberdeen made this dream become a reality. Dr Ho Kai provided the money and local connections, Dr Patrick Manson the organisational ability, and Dr James Cantlie the enterprise and dedication that would ensure success. Ho Kai was born in Hong Kong in 1857. His family was prosperous in commerce and his father, the Reverend Ho Tsun Shin-who worked for the London Missionary Society-had inherited numerous properties. In 1874 he sent his son to study medicine at Aberdeen. The reason for this choice of medical school is uncertain, but the name of that northern city would have been well known. Lord Aberdeen had been Secretary of State for Foreign Affairs at the end of the first Anglo-Chinese war and had endeavoured to curb the greed of the opium magnates. Ho Kai graduated in medicine-the first

Woodend General Hospital, Aberdeen AB9 2 YS

JAMES KYLE, DSC, FRCS, consultant surgeon

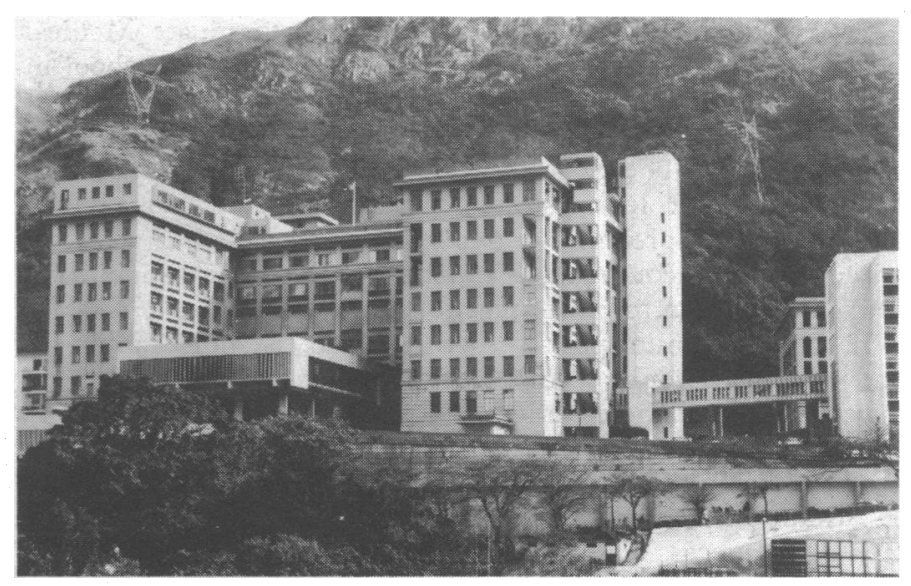

Queen Mary Hospital, Hong Kong (1937).

Chinese student to do so-in 1879; he then moved to St Thomas's Hospital, London. While in London he studied law, wasadmitted to Lincoln's Inn, and was called to the Bar in January 1882. One month earlier he had married Miss Alice Walkden at Upper Norwood, and shortly afterwards the couple returned to Hong Kong. Two years later Alice Ho Kai died from typhoid fever.

When it became clear that a proper hospital was desirable, Dr Ho Kai offered to put up the money, the building to be named in memory of his first wife. The Alice Memorial Hospital was founded in 1887 at the junction of Hollywood Road and Aberdeen Road.

Six years later, Mr Davis generously gave the money to found another hospital, the Nethersole, on Bonham RoadNethersole being his mother's maiden name. Early this century the need for a separate maternity hospital became apparent; again, Dr Ho Kai provided the money to build it. Furthermore, his sister, Ho Miu Ling, erected a hospital on Breezy Path. Thus in under two decades the Ho family was responsible for three new hospitals in Hong Kong, an act of generosity that is probably without parallel anywhere in the world. These four hospitals were the teaching hospitals for the college of medicine. Rebuilding before and after the second world war resulted in all of them being sited on Bonham Road. The lengthy name of the joint hospital, the Alice Ho Miu Ling Nethersole, rightly perpetuates the names of those families who did so much to help the community in which they lived.

As well as Dr Ho Kai, the medical staff attending at the first Alice Memorial Hospital were Drs Gerlach, Jordan, Noble, Francis Clark, James Cantlie, and Patrick Manson. Six months after the hospital opened they had founded a "College of Medicine for Chinese in Hong Kong." The intention was to train doctors for service not only in China but also elsewhere in East Asia. The college had the organisation familiar in a Scottish university, complete with general council, rector, and rector's 
assessor. At the first meeting of the senate on 30 August 1887, Patrick Manson was appointed dean and James Cantlie the secretary. The court invited the viceroy of Canton to become patron of the college. In his acceptance, Li Hung-Chang stated: "There is no doubt that when your admirable project is achieved it will be appreciated and imitated, and that it will through your students be a blessing to China."

Patrick Manson, of Orcadian stock, was born in 1844 at Oldmeldrum, a few miles north of Aberdeen. He passed his final examinations in medicine by the age of 20 , and had to wait a further year before he could graduate. He obtained his MD the following year and proceeded at once to Formosa, where he lived for five years. Manson next worked for 13 years at Amoy, on the South China coast. Filarial infestation was prevalent. At Amoy Manson discovered the nocturnal periodicity of the responsible parasite, and began to develop his theories on the transmission of disease by mosquitoes. His gardener, and the gardener's hut, played a crucial part in the experiments. A "hot-gospeller" finally made Manson decide to move from Amoy to Hong Kong at the end of 1883. Thus he was well placed to take an active part in the work of the Alice Memorial Hospital and in founding a medical college-he had already founded the Hong Kong Medical Society.

James Cantlie was seven years younger than Manson. He was born on a farm near Dufftown, in the heart of whisky distillery country. At the University of Aberdeen he attended the faculty of arts wearing a kilt. After graduating MA in 1871, he entered the faculty of medicine, but was persuaded to pursue his clinical studies at Charing Cross Hospital, London, by his friend Mitchell Bruce. He obtained his MB at Aberdeen in 1875, and by the age of 27 was assistant surgeon at Charing Cross Hospital. He founded the Volunteer Medical Staff Corps, predecessor of the RAMC(T), but a warning of the dangers of city life which he gave in 1885 aroused so much public interest and professional hostility that he felt it prudent to join Manson in Hong Kong, where he arrived the following year.

\section{Famous students}

The new College of Medicine offered a five-year course in Western medicine. Although intended principally for Chinese students, the language of instruction was English. Lessons in Latin (a useless language to the Chinese) were provided during the first five years. Later the absence of Latin from the curriculum caused trouble with the GMC in London. The first licentiates of the school received their diplomas from the governor on 23 July 1892 . They were Sun Yat Sen and Kong Ying-wa; the future president of the Republic of China qualified "with high distinction."

The Colonial Government maintained a register of licentiates,
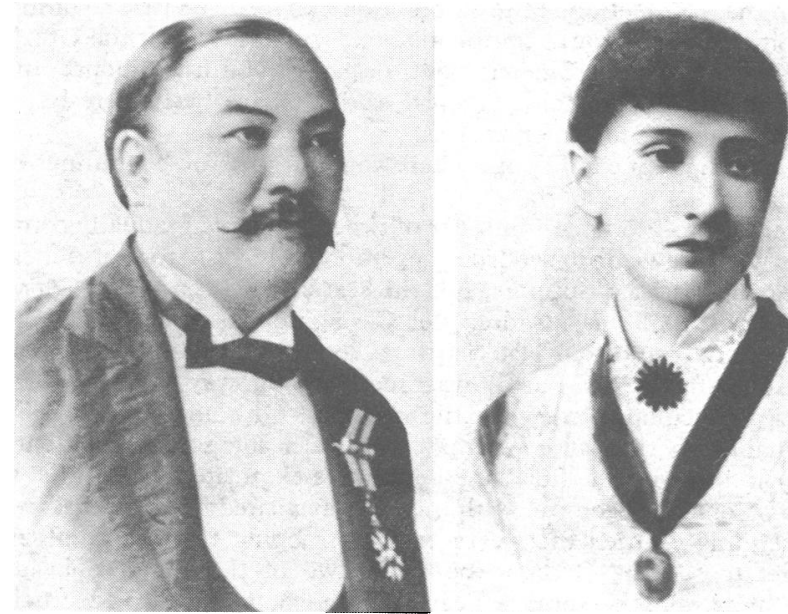

Sir Kai Ho Kai (1857-1914) and his wife Alice Ho Kai (née Walkden; died 1884). but traditional Chinese herbal doctors could practise freely. Between 1901 and 1909 attempts were made to obtain recognition of the College's training by the GMC. The board of the Scottish triple qualification accepted it, but it was not until the end of 1909 that the GMC agreed to accept the preliminary examinations as counting towards eventual full registration.

Patrick Manson taught medicine in the college for almost two years before he returned to Britain, where, with the help of Joseph Chamberlain, he founded the London School of Tropical Medicine. James Cantlie was professor of anatomy and of surgery and after Manson's departure was dean until 1897. In fact, the Cantlies had been allowed to return to Britain early in 1896, and they had a chance encounter with Dr Sun Yat Sen in Honolulu on their way home to London. Later that year he stayed with them at 46 Devonshire Street. On 11 October, while on his way to join the Cantlies, Sun Yat Sen was seized by two agents and forced into the Chinese Legation at the corner of Portland Place and Weymouth Street. There the prisoner was informed that because he was a revolutionary the Manchu authorities intended smuggling him back to China, where he would be beheaded. It took six days for Sun to get two English servants to carry an urgent message to Devonshire Street. Cantlie at once tried to get the police, Scotland Yard, The Times, and the Foreign Office to intervene, but it was a weekend and nothing happened. Official action under Lord Salisbury did not start until 20 October, the legation being carefully watched by detectives posted by Cantlie. Sun Yat Sen was eventually freed three days later.

The most famous licentiate of the Hong Kong Medical College made 10 unsuccessful attempts to overthrow the Manchu dynasty. When the last successful revolution started, Sun Yat Sen, like Lenin, was caught out of position (in Denver, Colorado). It was while making his circuitous way to the scene of action via England that Mrs Cantlie handed him the telegram offering him the presidency of China. When Cantlie returned to England, he became interested in first aid and ambulance. Among the pupils at one of his classes in 1914 was a slender Indian called M K Gandhi. Thus James Cantlie had the unique distinction of having taught the future leaders of the world's two most populous nations.

\section{College with many benefactors}

Dr Ho Kai held the chair of medical jurisprudence at the college until 1906. He was active in building and in education, and for 24 years was a member of the legislative council. He was knighted for his public services in 1912, and died two years later. Many other Chinese and expatriates donated money to the hospitals that taught medical students and nurses. In 1889 a Venetian merchant, Mr E H Belilios, offered to erect a separate college building, but unfortunately a site could not be found. In $1907 \mathrm{Dr} H o$ Kai arranged a similar offer from $\mathrm{Ng} \mathrm{Li} \mathrm{Hing;} \mathrm{the}$ public was to be asked to subscribe to an endowment fund. At this time, the name of the college was changed to the Hong Kong College of Medicine. The public appeal was postponed on account of a trade recession, but planning for a new building went ahead. The initial tenders were too high and modifications were suggested. Then, in 1908, the governor announced that a Parsee gentleman, Mr H N Mody, had promised $\$ 150000$ for a new university.

This startling proposal immediately altered the entire scene. Wisely, the college court decided that if it did join the university it should keep its new medical buildings together. There was disagreement about where the university should be sited. Dr Ho Kai canvassed the opinions of past and present college students on this point. They agreed that it should be at the junction of Pokfulam and Bonham Roads-and that is where the university was built. From 1909 onwards the court associated itself fully with the university committee. Frederick, Lord Lugard, the last of the great proconsuls, must have found the college delegates a determined and hard-headed group-the "no detriment" 
clauses for staff and students which they had written into the agreement signed with the university on 15 March 1912, would bring joy to the heart of any BMA negotiator.

Dr Francis Clark was appointed dean of the faculty of medicine in July 1912. He had taught physiology in the college for many years and been dean there after Cantlie left. The college could have granted diplomas until 1917, but the last court meeting was held on 14 January 1915 when Sir Francis May (a former college rector), the governor of Hong Kong and chancellor of its university, presented the last diplomas.

To return once again to the tarmac at Kai Tak airport: Dr Ho Kai realised that Kowloon Bay was shallow and suitable for land reclamation. He formed a property company with a local photographer, $\mathrm{Mr} \mathrm{Au} \mathrm{Tak}$, with the object of reclaiming part of the bay to build a garden city. Not until 1924, 10 years after his death, did the first filling-in operations begin. Within a year, some planes flew from the new flat land, but only after the area had reverted to the Government and a flying club was started in 1929 was the position of the present airport finally determined. Its runway was extended on the landward side by the Japanese during the last war. In recent years there have been further extensions out into Kowloon Bay, confirming that, in matters of land reclamation, Sir Kai Ho Kai displayed the same vision and initiative that he had shown in founding Hong Kong's hospitals, its college of medicine, and, finally, its university.

I am grateful to Professor and Mrs M Roberts, the late Sir Lindsay Ride, Dr C T Smith, Mr A I Diamond, and Dr E H Paterson of Hong Kong and the Honourable Society of Lincoln's Inn, London, for their help.

\section{MATERIA NON MEDICA}

\section{Thin ice}

Every year I look forward to the winter because even in a place as southerly (and civilised) as Stratford at least one day of coarse skating or skiing per year can be guaranteed. January 1979 was a bonanza month with skateable ice practically every day, and even snow. Remote canals and canal feeder ponds have been frozen hard and so have those delightfully safe flooded meadows near the Avon, where one night we skated by moonlight and drank Glühwein from vacuum flasks.

It has always amazed me that so few people in this country take advantage of winter sports when they are literally there on their doorstep. Instead they flock in their hundreds to sample packaged skiing holidays in the Alps or in distant Scotland, where a Cairngorm day ticket now costs $£ 6$. Why not invest in a second-hand pair of skis and trundle down the local wolds and slopes? It will not be so glamorous but it may be more fun.

One weekend I took my skis from Widdup reservoir to Todmorden in Yorkshire across such a bleak and lonely moor deep in snow that its pure desolation made my soul glad.

I suppose what puts people off is those ghoulish newspaper reports. "Three men drown in local pond." Skating on thin ice needs a lot of loaf, and the most important consideration is a shallow pond. Then make a hole in the ice with your heel and if the ice is at least an inch and a half thick it is probably safe to go. A companion with a length of climbing rope is a useful aid, and a long pole if you are unlucky enough to fall in.-HAMISH G NICOL (general practitioner, Stratford upon Avon).

\section{On losing a passport in Peru}

Titicaca is an enormous lake lying in the Andes at about $14000 \mathrm{ft}$. On it are inhabited islands made of reeds, boats made of reeds, and a ferry boat designed on the Clyde which plies between Peru and Bolivia. It is said to have been transported piecemeal and reconstructed on arrival. I crossed one night in a comfortable British-style cabin and listened to the roar of African lions. A mad dream ? No: a circus was crossing on the same boat.

From Lima I had flown to Arequipa $(7761 \mathrm{ft}$ ) and spent three interesting days acclimatising myself to altitude. Thence I took a train (again obviously British built) which went up to $15000 \mathrm{ft}$ and then down about $1000 \mathrm{ft}$ to Puno. This day-long and fascinating journey gave one a chance to look at the varying landscape, the altiplano with its flocks of llamas and the attendant women, always spinning brilliantly coloured llama wool on bobbins and wearing hats that looked like frilled shallow lampshades. I stayed the night in Puno in order to travel to Cuszco and Macchu Pichu and returned to Puno to catch the ferry to Bolivia.

On the night I stayed in Puno my passport was lost and found. At the station, when wishing to tip the porter, I saw that my handbag was open; but my purse and note case were safe. However, when the hotel receptionist asked for my passport it was not to be found. Perhaps because of hypoxia I felt no anxiety. The bellhop spoke, "The police radio they find a passport. You give me money and I fetch it." I smiled at the less-than-innocent child and said, "You fetch passport and then I give you money." A charming young Bolivian with perfect English offered to drive me to the police station.
Once there he explained my predicament to two huge, heavily armed policemen wearing greatcoats down to their ankles. One of them vanished and returned with a trim blonde lieutenant. Oh yes, a passport had been found by a detective. It was $9 \mathrm{pm}$ so probably he was at home having his supper, but he would come at once. (Thoughts of my homeland-Come tomorrow morning when the office opens and we will see what can be done.) Very soon a touzle-headed young man appeared. He had noticed me at the station and seen a man close behind whom he thought was "of my party." The man stooped and moved away quickly. The detective also moved quickly, seized and searched the man, and found my passport. With one finger of each hand the detective typed out a form of receipt. While he was doing this I asked the kind Bolivian if I should give him something. The Bolivian shrugged. "He was only doing his duty." He suggested the equivalent of 50p. That seemed too little to me. So when the detective handed me my passport and we shook hands I palmed him about $£ 1$. He took it without the quiver of an eyelid.

As we drove back the Bolivian asked, "Did you give him anything ?" I laughed. "Didn't you see ? I must be very expert. Perhaps I have chosen the wrong profession!"-M PICKFORD (professor of endocrinology, Nottingham).

\section{In search of Last Suppers}

"Have you visited the offices ?" asked the young Italian businessman in immaculate English. For a moment I didn't understand what he meant. It was Saturday morning in Florence, and we were both standing outside the cenacolo (refectory) of the church of Santo Spirito. In spite of a notice indicating that it was open to the public, the large wooden door remained obstinately closed-for the second day running as far as I was concerned.

"Do you like Orcagna ?" he had asked. "I've come from Venice to see the frescoes."

"I've come all the way from England" I said with a bitter laugh. It was then that he mentioned the offices. I quickly realised that he didn't mean somewhere we could complain about the closure, but the Uffizi, Italy's best known art gallery but originally built to house the bureaucracy of the Medicis. "Yes," I said, "I have been there but I prefer the convents and monasteries."

"I agree," he replied. "That's where you find the true beginnings of Florentine art."

We've been to Florence a number of times and have gradually come to select what we want to see from her impossibly vast store of riches. This year it was Last Suppers, but the search has been pretty frustrating. Sant' Apollonia (Andrea del Castagno) has been chiuso per restauro restauro since our last visit in 1976 and we didn't realise that San Salvi (Andrea del Sarto) was such a long way out. Still we renewed our acquaintance with the beautiful Ghirlandaio at Ognissanti (thanks to the same plump priest with the same threadbare sandals) and saw for the first time Perugino's exquisite fresco in Sant' Onofrio. Alone in refectories with these rarely visited masterpieces, we condescendingly pitied the weary crowds trooping round the Uffizi. I did get to see the Orcagna but only two of the apostles' heads remain, and even the sombre beauty of the better-preserved crucifixion above couldn't assuage my current appetite for Last Suppers. ALEX PATON (consultant physician, Birmingham.) 